\title{
Knowledge about Intestinal Worm Infection and Helminthiasis in Pregnant Women
}

\author{
M. Mutalazimah ${ }^{1 *}$, Luky Mustikaningrum ${ }^{1}$
}

${ }^{1}$ Department of Nutrition Science, Faculty of Health Science, Universitas Muhammadiyah Surakarta, INDONESIA *Corresponding Author: mutalazimah@ums.ac.id

Citation: Mutalazimah M, Mustikaningrum L. Knowledge about Intestinal Worm Infection and Helminthiasis in Pregnant Women. Electron J Gen Med. 2020;17(3):em215. https://doi.org/10.29333/ejgm/7876

\section{ARTICLE INFO}

Received: 28 Dec. 2019

Accepted: 19 Feb. 2020

\begin{abstract}
Background: Intestinal worm infection brings negative impact in weakening health condition, nutrition, and intelligence. One of the factors that causes intestinal worm infection in pregnant women is the low knowledge of pregnant women about the importance of the food hygiene. This research aims to analyze the correlation between knowledge about intestinal worm infection and helminthiasis of pregnant women.

Method: This study used observational cross sectional design. Samples were taken from the second and third trimester pregnant women in Community Health Center Kemusu 2, Boyolali District, Central of Java, Indonesia, as many as 205, with simple random sampling as the sampling technique. Knowledge about intestinal worm infection was measured by questionnaire of knowledge about intestinal worm infection. Data of intestinal worm infection was obtained from laboratory test with native method. The correlation test between knowledge and helminthiasis used rank Spearman's rho.

Conclusion: The knowledge about intestinal worm infection was considered low at $43.9 \%$ and the subjects that suffered intestinal worm infection (Ascaris lumbricoides) were $37.1 \%$. There is a correlation between knowledge about intestinal worm infection and helminthiasis of pregnant women $(p=0.001)$. The suggestion from this study is that there is a need to improve the level of knowledge about intestinal worm infection by women empowerment and promotive-preventive program improvement, so that it can reduce the risk of intestinal worm infection in pregnant women.
\end{abstract}

Keywords: knowledge, intestinal worm infection, pregnant women

\section{INTRODUCTION}

Intestinal worm infection is a health problem that needs serious handling, especially in the tropical area because quite a lot of residents suffer from intestinal worm infection. Intestinal worm infection is one of the most common infectious diseases in developed countries. In Indonesia, intestinal worm infection is still a major problem for the case of iron deficiency, anemia, since it is estimated that worms suck blood 2-100 cc per day (1). The global burden due to the most important neglected tropical diseases caused by helminthic and protozoal infections (2).

Intestinal worm infection has a negative impact on the patient. This disease can lead to weaken health conditions, nutrition, intelligence and productivity of the patients so that it economically causes many losses, because it causes loss of carbohydrates and protein and loss of blood (anemia). Inadequate maternal micronutrient status has significant potential to influence many development processes in the fetus and in breastfed infants, with immediate and long-term consequences. Interventions that prevent or reverse the effects of poor initial nutrition programs can have major implications for improving the health of future generations (3). Low economic societies have a high risk of suffering intestinal worm infection because of the lack of ability in maintaining hygiene and environmental sanitation of the place they live in (4). Ojja et al. (2018) found that older age, not hand washing with soap after defecation, eating vegetables and fruits without washing them, improper disposal of youngest child faeces, having caretakers with tertiary education and not deworming PSAC regularly were statistically and independently associated high risk for infections with soil transmitted helminth (STH) (5).

Research of Faridan et al. (6) showed that the infections of intestinal worms in primary school students are not only influenced by one of aspects of hygiene that is the nails hygiene, but also influenced by some aspects of environmental sanitation and other aspects of personal hygiene, such as washing hands before eating after playing with soil and after defecation, and always keep the environment clean.

One factor of intestinal worm infection is caused by knowledge factor of pregnant women about the importance of food hygiene that they consume. That is a knowledge on how to clean, wash, and cook foodstuff, and the hygiene of the cookware used. The higher the knowledge of pregnant women about the importance of hygiene will reduce the occurrence of intestinal worm infection, while the lower the knowledge of pregnant women, the more risk they will suffer from intestinal worm infection. Sometimes pregnant women with low 
knowledge will ignore how to choose, clean and cook the food properly. That is why the knowledge is needed to avoid the occurrence of intestinal worm infection (7). Pregnant women need to pay attention to their eating habits and the supplements consumed in order to reduce the occurrence of intestinal worm infection that can cause anemia, premature birth and low birth weight (8).

Sulianty (9) research results states that the knowledge associated with the prevalence of intestinal worm infections is due to the lack of knowledge about the intestinal worm infection. The low education of pregnant women is usually indicated by ignoring the hygiene of cooking utensils. Intestinal worm infection occurs when humans swallow worms' eggs through food, drink, or through the skin.

Most pregnant women around the area in Community Health Center of Kemusu 2, commonly have last education only up to elementary school and junior high school with limited or low knowledge. The results of preliminary survey of intestinal worm infection in pregnant women in 2016 at Community Health Center of Kemusu 2 showed that $40 \%$ of them suffered from intestinal worm infection. Based on the above problems, the researcher is interested to examine the correlation between knowledge and intestinal worm infection of pregnant women at Kemusu 2 Public Health Center, Boyolali District.

\section{MATERIALS AND METHODS}

This research is an observational research with cross sectional research design that was conducted in October to December 2016. The research was conducted at Community Health Center Kemusu 2, Boyolali District, Central of Java, Indonesia. The samples of the study was 205 pregnant women second and third trimester used simple random sampling technique. Inclusion criteria in this study are the pregnant women who are able to communicate well and willing to be a research respondent while exclusion criteria in this study are pregnant women who take intestinal worm infection medicine and pregnant women whose feces have been checked and positively suffering from intestinal worm infection. The variables in this study are the knowledge as independent variables and intestinal worm infection of pregnant women as dependent variables.

The data collection technique of respondent identity was done by structured interview using questionnaire. The data of knowledge level of pregnant women about intestinal worm infection was done by giving questionnaire to respondents about intestinal worm infection that have been tested its reliability through several stages, literature review, domain identification, and trial questionnaire. Instrument reliability test results obtained Cronbach alpha value of 0.898 and $r \geq 0.3$ as much as 20 items. The data of intestinal worm infection was obtained from laboratory personnel of Community Health Center Kemusu 2 by conducting feces examination of pregnant women by using native method. Type of worms checked was Ascaris lumbricoides.

A univariate analysis was done by describing the independent and dependent variables represented by the frequency distribution table. The bivariate analysis was done by testing the normality of the data by using KolmogorovSmirnov test and testing the correlation by using Spearman's rho correlation test for abnormal distribution data. This study was approved by the Ethics Committee for Health Research
Table 1. Characteristics of Research Subject

\begin{tabular}{ccc}
\hline Variables & Frequency & Percentage \\
\hline Age (Years) & & \\
At Risk (<20 or $>35)$ & 46 & 22.4 \\
Not At Risk (20-35) & 159 & 77.6 \\
Education Level & & \\
Elementary School & 50 & 24.4 \\
Junior High School & 100 & 48.8 \\
Senior High School & 55 & 26.8 \\
Low & & \\
Moderate & 90 & 43.9 \\
High & 30 & 14.6 \\
Knowledge Level & 85 & 41.5 \\
Positive & & 37.1 \\
Negative & 76 & 62.9 \\
\hline Intestinal Worm Infection & 129 & \\
\hline
\end{tabular}

(FEKP) Faculty of Medicine, Universitas Muhammadiyah Surakarta with ethical clearance number No:509/B.1/KEPKFKUMS/XII/2016.

\section{RESULTS}

Characteristics of the subjects in this study are age and education of pregnant women. The result of characteristic of subject can be seen in Table 1.

Based on the results of the study, it shows that among 205 pregnant women (respondents) there are $22.4 \%$ of pregnant women who are $<20$ or $>35$ years old considered at risk. The results of this research are higher than the research results of Hidayah et al. (10), which showed that the pregnant women included in risk groups were $57.10 \%$. Gibbs (11), research results showed that the younger the age of the pregnant women, the higher the risk of miscarriage, premature delivery, getting infected, anemia, and maternal mortality.

The data of education level of pregnant women among 205 respondents there were $24.4 \%$ who graduated from elementary school, $48.8 \%$ graduated from junior high school, and $28.8 \%$ graduated from senior high school. The result of Handayani's (12) study showed that 38 pregnant women as much as $52.65 \%$ were classified as having basic knowledge level. According to Pradono (13) the low education level of pregnant women can highly influence their health knowledge.

In this research, the data of intestinal worm infection of pregnant women were obtained by interviewing the pregnant women by using questionnaire of knowledge about intestinal worm infection. Pregnant women were categorized as having a low knowledge level if the score of answering the questionnaire is <mean - $1 \mathrm{SD}$, categorized as having a moderate knowledge level if the knowledge score is between the mean - 1SD to mean $+1 \mathrm{SD}$, and categorized as having a high knowledge level if the score is $>$ mean $+1 \mathrm{SD}$.

In this research, the data of intestinal worm infection was obtained by examining pregnant woman's feces by using native method. The results of intestinal worm infection data showed that there were $37.1 \%$ subjects infected intestinal worms.

The variables in this research are pregnant women knowledge about intestinal worm infection, and infection of intestinal worms. Descriptive statistics based on the variables studied can be seen in Table 2 .

Table 2 shows that the average knowledge of pregnant women about intestinal worm infection by $81 \pm 12.4$ with a 
Table 2. Results of Analysis of Descriptive Statistics

\begin{tabular}{ccccc}
\hline Variables & Mean & SD & Minimum & Maximum \\
\hline Score of Knowledge & 81 & 12.4 & 45 & 100 \\
\hline Number of worms in the feces & 0 & 0.94 & 0 & 5 \\
\hline
\end{tabular}

minimum value of 45 were classified as low knowledge level and a maximum value of 100 were classified as high knowledge level. Results of the knowledge score were obtained from the results of the answered questions and questionnaires of the respondents. The examination of intestinal worm infection was conducted by examining the worm eggs found in the feces of the subjects, the results of the average number of worm eggs found in the feces were $0 \pm 0.94$ with a minimum value of the number of worm eggs of 0 classified as negative which means not infected by intestinal worms and the maximum value of the number of worm eggs of 5 are classified as positive which means infected by intestinal worms.

\section{DISCUSSION}

The age of pregnant women is divided into 2 categories, at risk age ( $<20$ or $>35$ years old) and not at risk (20-35 years old). The education level of pregnant women was measured based on the level of formal education grouped into 3 basic educations, pregnant women who completed elementary school education, junior high school education, and senior high school education. Gibbs et al. (11) research results showed that the younger the age of the pregnant women, the higher the risk of miscarriage, premature delivery, getting infected, anemia, and maternal mortality.

Pregnant women with senior high school education level are at low risk for anemia while pregnant women with junior high school education level are at a high risk for anemia. Diazquijano et al. (14) research results also states that the low level of education will lead to various limitations of knowledge, attitude and practice in dealing with nutritional problems. The nutritional knowledge of pregnant women can determine the amount of food and type of food consumed, processed, served and distributed food to all family members. The low education and socio-economy would affect the ability of families to get health care facilities (15).

Pregnant women who are highly educated are better in behaving properly to prevent intestinal worm infection during pregnancy than low educated pregnant women (16). According Melaku et al. (17), maternal education is a main factor affecting nutrition pattern. The higher one's education level, it will be the easier for him in learning the nutrition and health information, so that his knowledge of nutrition and health will get better. Good nutrition will influence on the development of human resources, due to malnutrition have a negative impact on health and can hinder the quality of human resources. Maternal nutrition, is an integral part to ensuring the long-term health and nutritional status of both the mother and her growing fetus (18).

Knowledge of the intestinal worm infection can affect the health. Intestinal worm infection caused by infection of Soil Transmitted Helminth, a class of worms that breed on the ground and transmitted through the ground. This intestinal worm infection often found in people who live in tropical, humid or rural areas (19). Knowledge of intestinal worm infection in terms of food hygiene, that food can be contaminated with microbes. In terms of food serving, unhygienic food will lead to the epidemic of diseases and worm eggs can get into the body (20), the data of pregnant women's knowledge about intestinal worm infection in this research was obtained by interviewing the pregnant women by using questionnaire of knowledge about intestinal worm infection.

The data of intestinal worm infection in this research were obtained by examining pregnant women' feces by using native method. This method is used for fast and good examination for severe infections, but for mild infections it is difficult to find the worm eggs. The effectiveness of this method, it can inspect all species of worm eggs easily and quickly, which also needs little cost and equipment. The results of this study differ from the research of Bolka and Gebremedhin (21), in Ethiopia, showed that pregnant women infected by intestinal worms were $92.3 \%$. Someone is diagnosed infected by intestinal worms if in the examination of his feces, it is positively found one or more worm eggs, whereas if worm eggs are not found in the feces so the pregnant woman is negatively infected (22).

The results of this study showed that the average knowledge of pregnant women about the infection of intestinal worm was $81 \pm 12.4$ with a minimum of 45 and a maximum value of 100 . The examination of intestinal worm infection showed that the average number of worm eggs found in the feces was $0 \pm 0.94$ with a minimum value of the number of worm eggs of 0 was classified as negative and the maximum value of the number of worm eggs of 5 was classified as positively infected by intestinal worms.

Based on rank Spearman's rho test, obtained there is a correlation between knowledge of intestinal worm infection and helminthiasis $(p=0.001)$ in pregnant women in Community Health Center Kemusu 2, Boyolali District. This findings in line with the results of research conducted by Rusmanto and Mukono (23), showed that there is a correlation between knowledge and intestinal worm infection. This study is also coherent with the research of Hakli et al. (24), concluded that one's adequate knowledge about nutrition is expected to change his behavior in choosing nutritious foods, preparing the food in a balanced diet and preventing intestinal worm infection.

The knowledge of pregnant women about the infection of intestinal worm is low because they do not understand the causes, symptoms, ways of transmission, and prevention of intestinal worm infection. In this case, pregnant women do not know how to prevent the occurrence of intestinal worm infection. Knowledge is a very important domain to develop someone's behavior (24). Although a pregnant woman has a low education but if she gets good health information through various media, it will be able to enhance her health knowledge.

\section{CONCLUSIONS}

There is a correlation between knowledge about intestinal worm infection and the infection of intestinal worms of pregnant women at Community Health Center of Kemusu 2, Boyolali District, Central of Java, Indonesia ( $p=0.001$ ). The implication of the results of community nutrition program policies, it is still necessary to improve the knowledge level about intestinal worm infection so that it can reduce the risk of intestinal worm infection in pregnant women. 


\section{REFERENCES}

1. Syahnuddin M, Gunawan G, Sumolang PPF, Lobo LT. Hubungan Anemia Gizi dengan Infeksi Kecacingan pada Remaja Putri di Beberapa SLTA di Kota Palu. Media Penelitian Dan Pengembangan Kesehatan, 2017;27(4):2238. https://doi.org/10.22435/mpk.v27i4.5607.223-228

2. Knopp S, Blum J, Neumayr AL, Keiser J, Hatz CF. Neglected tropical diseases: diagnosis, clinical management, treatment and control. Swiss Medical Weekly, 2012;142(w13727):19-22. https://doi.org/10.4414/smw. 2012.13727 PMid:23180107

3. Cetin I, Demir C, Prescott SL. Impact of Micronutrient Status during Pregnancy on Early Nutrition Programming. Annuals of Nutrition \& Metabolism, 2019;74:269-78. https://doi.org/10.1159/000499698 PMid:30939482

4. Harhay MO, Horton J, Olliaro PL. Epidemiology and Control of Human Gastrointestinal Parasites in Children. Expert Review of Anti-Infective Therapy, 2010;8(2):219-34. https://doi.org/10.1586/eri.09.119 PMid:20109051 PMCid:PMC2851163

5. Ojja S, Kisaka S, Ediau M, Tuhebwe D, Kisakye AN, Halage $A A$, et al. Prevalence, intensity and factors associated with soil-transmitted helminths infections among preschoolage children in Hoima district, rural western Uganda. BMC Infectious Diseases, 2018;80:1-12. https://doi.org/10.1186/ s12879-018-3289-0 PMid:30119650 PMCid:PMC6098587

6. Faridan K, Marlinae L, Audhah NAl. Faktor-faktor yang Berhubungan dengan Kejadian Kecacingan pada Siswa Sekolah Dasar Negeri Cempaka 1 Kota Banjarbaru. Jurnal Buski, 2013;4(3):121-7.

7. Lubis R, Panggabean M, Yulfi H. Pengaruh Tingkat Pengetahuan dan Sikap Ibu terhadap Penyakit Kecacingan Pada Balita. Jurnal Kesehatan Lingkungan Indonesia, 2018;17(1):39. https://doi.org/10.14710/jkli.17.1.39-45

8. Huang L, Purvarshi G, Wang S, Zhong L, Tang H. The Influence of Iron-deficiency Anemia during the Pregnancy on Preterm Birth and Birth Weight in South China. Journal of Food and Nutrition Research, 2015;3(9):570-4. https://doi.org/10.12691/jfnr-3-9-2

9. Sulianty A. Pengaruh Kecacingan terhadap Kehamilan (Kadar $\mathrm{Hb}$, Tinggi Fundus Uteri) dan Persalinan (Lama Persalinan, Berat Badan Lahir Bayi). Media Bina Ilmiah, $2013 ;(1978): 42-5$.

10. Hidayah P, Wahyuningsih HP, Kusminatun K. Hubungan Tingkat Risiko Kehamilan dengan Kejadian Komplikasi Persalinan di RSUD Panembahan Senopati Bantul. Jurnal Kesehatan Vokasional, 2018;3(1):39. https://doi.org/ 10.22146/jkesvo.33877

11. Gibbs CM, Wendt A, Peters S, Hogue CJ. The Impact of Early Age at First Childbirth on Maternal and Infant Health. Paediatr Perinat Epidemiol., 2015;26(0 1):259-84. https://doi.org/10.1111/j.1365-3016.2012.01290.x PMid:22742615 PMCid:PMC4562289

12. Handayani SN. Hubungan Kadar Yodium Urin Dan KAdar Hemoglobin Ibu Hamil Dengan Berat Badan Lahir Bayi Di Wilayah Kerja Puskesmas Musuk I Kabupaten Boyolali. Universitas Muhammadiyah Surakarta, 2014:1-11.
13. Pradono J, Sulistyowati N. Hubungan antara Tingkat Pendidikan, Pengetahuan tentang Kesehatan Lingkungan, Perilaku Hidup Sehat dengan Status Kesehatan Studi Korelasi pada Penduduk Umur 10 - 24 Tahun di Jakarta Pusat. Buletin Penelitian Sistem Kesehatan, 2014;17(1):8995. Available at: https://media.neliti.com/media/ publications/20885-ID-correlation-between-educationlevel-knowledge-of-environmental-health-healthy-be.pdf

14. Diaz-Quijano FA, Martínez-Vega RA, Rodriguez-Morales AJ, Rojas-Calero RA, Luna-González ML, Díaz-Quijano RG. Association between the level of education and knowledge, attitudes and practices regarding dengue in the Caribbean region of Colombia. BMC Public Health, 2018;18(1):1-10. https://doi.org/10.1186/s12889-018-5055-z PMid:29338712 PMCid:PMC5771071

15. Marlina L, W J. Relationship of Formal Education, Mother Knowledge and Socioeconomic towards Soil Transmitted Helminths Infections among Elementary School Children of East. Jurnal Ekologi Kesehatan, 2012;11:33-9.

16. Purbadewi L, Ulvie YNS. Hubungan Tingkat Pengetahuan Tentang Anemia dengan Kejadian Anemia pada Ibu Hamil. Jurnal Gizi Universitas Muhammadiyah Surakarta, 2013;2(April):31-9.

17. Melaku YA, Gill TK, Taylor AW, Adams R, Shi Z, Worku A. Associations of childhood, maternal and household dietary patterns with childhood stunting in Ethiopia: Proposing an alternative and plausible dietary analysis method to dietary diversity scores. Nutrition Journal, 2018;17(1):1-15. https://doi.org/10.1186/s12937-018-0316-3 PMid:29378583 PMCid:PMC5789646

18. Dadi AF, Desyibelew HD. Undernutrition and its associated factors among pregnant mothers in Gondar town, Northwest Ethiopia. PLoS ONE, 2019;14(4):1-11. https://doi.org/10.1371/journal.pone.0215305 PMid:31009475 PMCid:PMC6476509

19. Boonjaraspinyo S, Boonmars T, Kaewsamut B, Ekobol N. A Cross-Sectional Study on Intestinal Parasitic Infections in Rural Communities, Northeast Thailand. Korean J Parasitol, 2013;51(6):727-34. https://doi.org/10.3347/ kjp.2013.51.6.727 PMid:24516280 PMCid:PMC3916464

20. Ahmed Z, Afreen A, Hassan MU, Ahmad H, Anjum N, Waseem M. Exposure of Food Safety Knowledge and Inadequate Practices among Food Vendors at Rawalpindi; the Fourth Largest City of Pakistan. Journal of Food and Nutrition Research, 2017;5(1):63-73. https://doi.org/ 10.12691/jfnr-5-1-10

21. Bolka A, Gebremedhin S. Prevalence of intestinal parasitic infection and its association with anemia among pregnant women in Wondo Genet district, Southern Ethiopia: A cross-sectional study. BMC Infectious Diseases, 2019;19(1):1-8. https://doi.org/10.1186/s12879-019-4135-8 PMid:31146689 PMCid:PMC6543579

22. Awaludin A, Nurkholis, Nusantoro S. Identify the diversity of helminth parasites in cattle in Jember district (East JavaIndonesia). IOP Conference Series: Earth and Environmental Science, 2018;207(1):0-5. https://doi.org/ 10.1088/1755-1315/207/1/012032

23. Rusmanto D, Mukono J. Hubungan Personal Higyene Siswa Sekolah Dasar dengan Kejadian Kecacingan. The Indonesian Journal of Public Health, 2012;8:105-11. 
24. Hakli G, Asil E, Uçar A, Özdogan Y, Yilmaz MV, Özçelik AÖ, et al. Nutritional knowledge and behavior of adults: Their relations with sociodemographic factors. Pakistan Journal of Nutrition, 2016;15(6):532-39. https://doi.org/10.3923/ pjn.2016.532.539 